\title{
Reflecting On The Modification Of A Summative Assessment Instrument To Redress Its Linguistic Complexity For Second-Language Learners In An ODL Context
}

C. H. Bothma, University of South Africa, South Africa M. C. Cant, University of South Africa, South Africa

M. N. du Toit, University of South Africa, South Africa

\begin{abstract}
This study attempted to determine whether simplifying the linguistic complexity of a written summative assessment instrument would improve the examination results of second-language learners; the academic literature suggests that linguistic complexity impacts negatively on the performance of second-language learners. The module chosen for the study was the capstone module of the marketing department at the University of South Africa, an open and distance learning institution. A 2007 examination paper was modified in an attempt to make it linguistically simpler and was used again in 2009. The results of first-language learners were compared with those of second language learners, who represent a significant component of the university's student population, across the two periods in question. The results were analysed using an independent two-sample t-test. The findings do not support the premise that simplifying the linguistic complexity of an assessment instrument would have a positive impact on the examination performance of second-language learners. The article highlights a number of issues and questions that require further research.
\end{abstract}

Keywords: Linguistic Complexity; Open and Distance Learning; Student Performance; Second-Language Learners

\section{BACKGROUND}

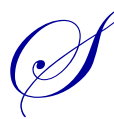

outh Africa is known as the 'rainbow nation', a name accorded to the country because of the heterogeneous nature of the local population (Gqola 2001). This population heterogeneity is reflected in the fact that South Africa officially recognises 11 official languages. It can be argued that this language heterogeneity, in turn, has had a detrimental effect on tertiary students who are expected to study at university either in English or Afrikaans, when neither of these two languages is the students' home language.

The University of South Africa (UNISA), the largest distance learning university in South Africa and one of the largest in the world (Unesco 2005), is particularly affected by language diversity. If one considers that the language of tuition at UNISA is either English or Afrikaans (only two of the 11 official languages in the country), then this state of affairs represents a significant challenge/barrier for more than $63 \%$ of the 282380 students studying at UNISA for whom these two languages are not their mother tongue (UNISA 2010).

At the same time, as with many other universities, UNISA is faced with the challenge of improving student pass rates, and ultimately throughput and attrition rates (Pityana 2009). Several authors have addressed the link between student performance and success, and the challenges faced by students whose home language is neither 
English nor Afrikaans (referred to as second-language learners - SLLs) (Howie 2004:159; Bharuthram 2006:12-14; Setati, Chitera \& Essien 2009:68-72; Maitland 2010:63-64). The challenge of improving student performance and throughput rates is, however, not only a university challenge, but also a departmental challenge. The Department of Marketing and Retail Management (DMRM), one of 13 departments in the College of Economic and Management Sciences at UNISA, faced with the task of improving student pass rate for their capstone module, 'Marketing Management', considered how the summative assessment challenge for English second-language learners could be made less daunting, and in so doing, improve the pass rate.

Following on from a brainstorming session within the DMRM, it was proposed that special effort should be put into reducing the level of complexity of the linguistics used in the summative assessment for the module in question. As a result of this initiative, a team of the senior lecturing staff within the department reworked a previous examination paper, endeavouring to reword the questions in order to make them linguistically and semantically simpler, while still testing the same application of the underlying theory. The newly formulated examination paper was then used in a subsequent examination period and the results of students who wrote the new paper were statistically compared with the results of students who wrote the previous paper using significance testing.

\section{LITERATURE SURVEY}

The introduction above positions the study as being about determining whether simplifying the linguistic complexity of the written component of the summative assessment of marketing students in the DMRM can positively impact upon the performance - specifically the pass rate - of second language learners (SLL) in marketing. To this end, the literature survey that follows starts out by defining what is meant by SLLs and strives to identify the many problems that such learners face, in order to provide the context within which student performance takes place. The main point that will be made is that the linguistic complexity of study material and assessment instruments is only one of many problems or challenges that SLLs face at university. The literature survey also defines what is meant by linguistic complexity and highlights the impact that linguistic complexity can have on student performance, particularly in an ODL context that a distance-learning institution such as UNISA is faced with. Finally, the literature survey describes the extent of SLLs within the DMRM and then addresses the need to examine the impact that linguistic complexity has on student performance within this segment of the DMRM's student community.

Attempting to define and describe students whose home language differs from the language of teaching and learning (LOTL) (Browning et al 2000), is a daunting task. There appears to be a lack of consensus in the academic literature as to the terminology used to describe students who learn using a language other than their home language. This view is supported by Tangen (2007) who argues that there is no single term to describe students who have English as a second language. Perusing the numerous articles on this topic, it would seem that the term most commonly encountered to described such learners is 'English second-language' (ESL) learners (Seeff-Gabriel 2003; Horn 2007; Tangen 2007; Kanjira 2008). There are, however, many other similar terms used in the literature to describe such learners (Lee 1997; Wang \& sGarcœa 2002; Mahabeer 2003; Abedi \& Gándara 2006; August \& Shanahan 2006; Al-Qarni 2008; Omidire 2009; Maitland 2010).

Notwithstanding the many terms discussed in the literature to described learners whose home language is not the LOTL, this article has adopted the term 'second-language learners' (SLLs) as used by August and Shanahan (2006) and Al-Qarni (2008). The reason for this is that in the case of terms such as ESLs, English-language learners (ELLs) (Abedi \& Gándara 2006), English additional-language (EAL) leaners (Bharuthram 2006), and English foreign-language (EFL) learners (Straker 2008), the focus is clearly on English as the second language, while in the case of SLLs the term does not prescribe that the LOTL should be English. As UNISA is a bilingual university with English and Afrikaans as the two main languages of tuition, and as the study addresses this bilingualism in its methodology, using the term SLLs makes more sense.

SLLs can be described as those learners whose home language is something other than the LOTL. The LOTL (in the case of UNISA, English and Afrikaans) may be their second language, and for some multilingual students, it may even be their third, fourth, or fifth language (Browning et al 2000). SLLs thus face the challenge of having to learn in a second language in addition to the many other typical problems faced by students studying at university. 
As language (in particular, the linguistic complexity of study material and assessment instruments) is but one of many problems faced by students studying at university, it is appropriate to consider the typical problems faced by students studying at university in order to provide a context for this study. It is quite feasible that any of these problems could impact on student performance and for this reason it is thought important to temper the research and subsequent discourse with the knowledge that 'something else' might be impacting upon student performance. The article returns to this point later in the discussion.

The typical problems that university students face can be divided into two main groups; those that relate to the personal circumstances of the student, and those that relate to the institution and its offerings that the student will ultimately be involved with. The personal factors that may impact upon student performance include the time the student has available for study, the background and culture that the student comes from, the financial constraints experienced by the student (Mhehe 2002), their personal behaviours, actions, motivations, and individual attributes (Boles 2008), their parents' education levels, the poverty they may have been subjected to (Abedi, Leon \& Mirocha 2003), their personality type and perceptions of the learning that they will receive (Irani, Scherler, Harrington \& Telg 2000), the geographic and economic barriers they face (Hummel 2010), their mental health (Anon 2006), as well as inequitable schooling conditions they may have encountered (Gándara, Rumberger, Maxwell-Jolly \& Callahan 2003). It is argued that, while both SLLs and English home-language learners may experience these above mentioned problems, in South Africa, particularly, many of these problems (poverty, poor or minimal schooling, difficult living circumstances, etc.) are endemic amongst the disadvantaged communities in the country that are mostly comprised of SLLs (according to Casale and Posel (2010) about 80\% of South Africans speak a home language other than English).

As far as the problems associated with the university and its offerings are concerned, these will include, but are not limited to, the nature and structure of the course they have registered for, the teaching methods employed (Reviere 2001), the extent and quality of the learning support they receive, the applicability of the curriculum to learners, the assessment they will encounter, the campus environment they will function within, (Boles 2008), the non-learning support they receive from their university (Adegbile \& Oyekanmi 2009), and the linguistic complexity of the learning and assessment they will encounter (Abedi 2004). Once again, both SLLs and English homelanguage learners experience similar problems with the institution, perhaps just at different levels of intensity. Furthermore, even English home-language learners may struggle with the challenges of academic learning and writing, just as SLLs do. SSLs, however, may also face the additional challenge of having to learn English as a second language concurrently with studying in the language. This is referred to as English language acquisition (ELA) (Wu \& Hsieh 2008).

In Figure 1 below, an attempt has been made to bring together in a summarised form most of the abovementioned factors that are likely to impact upon student performance. The figure highlights the fact that for SLLs (and, indeed, for other learners as well), student performance is dependent upon (a) comprehending the knowledge that is being imparted upon them (that is, understanding the work that they are being taught) (Ngwenya 2004; Abedi \& Gándara 2006; Setati, Chitera \& Essien 2009), and (b) expressing their understanding of this knowledge in the various forms of assessment (including formative and summative assessment) that the university requires of the student (that is, being able to explain what they understand about the work they have been taught) (Ngwenya 2004; Abedi \& Gándara 2006). In other words, there is a learning component and an assessment component and both of these components may impact upon performance. 

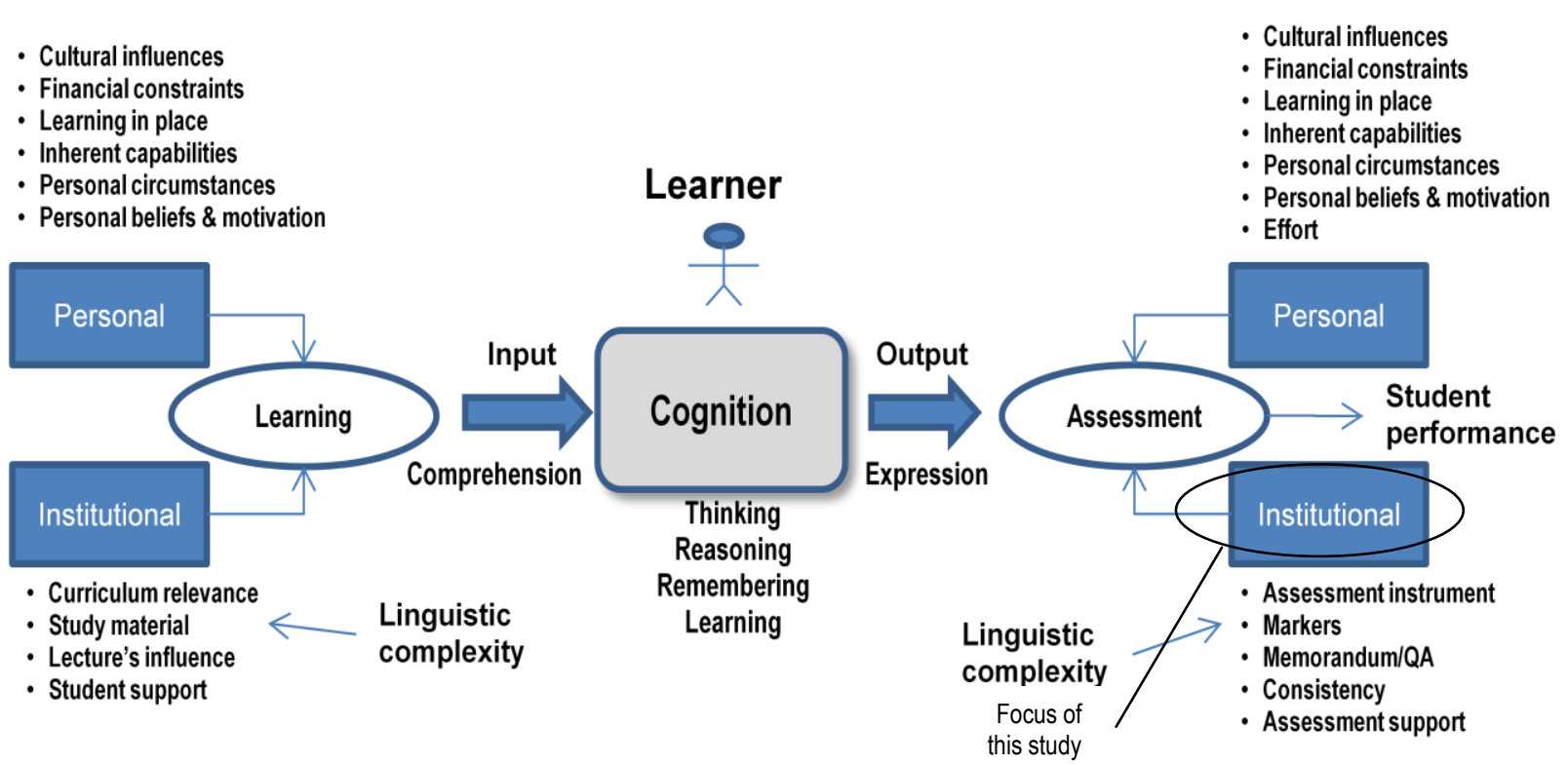

Figure 1: A summary of the factors impacting upon student learning

Abedi and Gándara (2006) in their research, attempted to identify the factors affecting SLLs' performance gaps (compared with first language learners) in their assessments. They identified both cognitive and non-cognitive factors, which they elaborated on in their article, as the two main determinants of student performance. In their discussion, they also highlighted several of the personal and institutional problems facing students that were outlined earlier in this section (which is captured in the figure above). Their cognitive/non-cognitive approach helped shape the structure adopted in Figure 1. The authors specifically highlighted linguistic complexity as one of the key problems facing SLLs.

The question arises, however, as to exactly what is 'linguistic complexity'? Defining linguistic complexity has proved to be elusive. The Research Centre for English and Applied Linguistics in their 2006/2007 annual report - drawing on the work of Hawkins (2007) - suggest that the task of defining linguistic complexity faces numerous problems, such as trade-offs in complexity between one part of the grammar and another; the lack of complexity metrics; the rules of grammar often not being not clearly definable; and the lack of a definition of complexity. Martin (2010) points out that "Despite the central importance of the concept of complexity for theories of language structure and processing, linguistic complexity remains a rather ill-defined - but often invoked - concept." Kusters (2003), in turn, points to various arguments that have been made against the notion of complexity, and against the possibility of examining complexity. These notions, he elaborates, are usually based on the claim that complexity in language cannot be examined, because complexities in one domain of language are balanced by simplicity in another domain (the 'trade-off' mentioned above), thus conforming with the widely held (but also contested) view that all languages are equally complex (Miestamo 2004:2). Several other authors also touch on the lack of definition of linguistic complexity (Miestamo 2004; Bane 2008).

Part of the difficulty in defining linguistic complexity stems from the fact that linguistic complexity can be viewed from different perspectives, namely an absolute and a relative perspective (Miestamo 2004). The absolute view of complexity, argues Miestamo, examines a language objectively in terms of its component parts using a range of language metrics. The evaluation is usually undertaken by a linguistic specialist or possibly using a software program. Relative complexity, on the other hand, examines a language in terms of the difficulty of processing or acquiring/learning a language from a individual point-of-view. This complexity is usually viewed from the perspective of a language user who could be a lay person or a linguistic specialist. In the second instance, it would be feasible to evaluate the linguistic complexity of an assessment instrument, for example, by asking either linguistic specialists, the lecturers or teachers involved, or even the students themselves, as to the difficulty of the 
assessment instrument in question. Kusters in his doctoral thesis (2003) supports this view by arguing that “... complexity is not a simple predicate attributable to language but a relation between two entities: a language and someone who evaluates the language."

With the abovementioned perspectives and levels of linguistic complexity in mind, the authors of this article now propose a definition of linguistic complexity:

Linguistic complexity can be viewed from either an objective or relative perspective. The objective perspective benchmarks a given text according to set metrics that attempt to quantify the difficulty of the text in terms of word and sentence length, density of words, extent of syntax used, etc. The relative perspective describes the difficulty a particular language user has with the process of interacting with, comprehending and responding to the text in question.

The process referred to above begins with an individual receiving input transmitted from others in the language concerned, either by reading and/or hearing the text in question. The individual then digests this input by cognitively comprehending its meaning, implication and context; that is, the individual tries to understand what is being communicated to him or her. Where feedback or response is required, the individual expresses him or herself in the same language either in written or verbal form as means of output to others so that they, in turn, may understand what the individual in question has communicated. An attempt was made to capture the essence of this process in Figure 1, outlined earlier in this section.

With a definition of linguistic complexity on hand, the article now addresses the implication of linguistic complexity on student performance in the open and distance learning (ODL) context that a distance-learning university such as UNISA finds itself. ODL can be defined as a teaching and learning approach that strives to open education and training to all and to free learners from the constraints of time and place (Unesco 2002). Thurlow, in her doctoral thesis (2004:12) and drawing on the works of others, explains that the hallmark of distance learning is the separation of teacher and learner in time and space with the control of the learning increasingly in the hands of the student rather than the teacher. She further points out that the interaction between student and teacher tends to be 'non-contiguous' and is normally mediated by print or some form of technology. The key role that the media plays in carrying across course content and overcoming the physical separation of teacher and learner is an important point (Thurlow 2004:13). It suggests that the learner is very dependent on both the content and the media and has little additional communication signals to draw on. For an SLL, the difficulty increases even further. If the language of the content is complex, the SLL is likely to struggle more than the first-language learner.

Vidanapathirana and Gamini (2009) point out that offering learning programmes only in English [or Afrikaans, in the case of UNISA] " ... solely to suit 'market needs' could have a high probability of undermining the entitlement of educational opportunities for the majority of prospective learners." They expand on this point by arguing that a mixture of socio-cultural, economic, political and psychological issues may aggravate the situation when learners who are less proficient in English or Afrikaans have to compete with first language English learners. They conclude that the 'language barrier' for SLLs essentially works against the ODL objective of increasing outreach and expanding education opportunities (Vidanapathirana \& Gamini 2009).

In the introduction, the concern with student performance as well as low throughput rates was proposed as a key reason for considering the linguistic complexity of the DMRM's assessment instrument. The argument was put forward that because of the linguistic complexity of assessment instruments for SLLs, such individuals may struggle with these assessments and may underperform and even drop out as a result. The academic literature is replete with articles and research on student performance, throughput and attrition rates. There have been many authors that have written about this topic over the years, some of whom have also developed concomitant models of student attrition. These authors include Spady (1970), Tinto (1975), Pascarella (1980), Bean (1982), Bean and Metzner (1985), Kember (1989), Cabrera, Nora and Castaneda (1992), Tinto (1993), Mackinnon-Slaney (1994), Ozga and Sukhnandan (1998), Astin (1998), DesJardins, Ahlburg and McCall (1999), Bean and Eaton (2000), DeRemer (2002), Grimes (2002), Stratton, O'Toole \& Wetzel (2006), Subotzky and Prinsloo (2010), Van Zyl, Subotzky and Leibenberg (2011) and Van Schoor (2011). However, few of these authors explicitly identify language as a factor impacting on student attrition, although it could be argued that language is implicit in some of the factors that they put forward as contributing to student attrition. 
In contrast, Cao and Gabb (2006:2) are two authors that have specifically argued that a link exists between language and student performance and attrition. Similarly, Pretorius, Prinsloo and Uys (2006) in their research of the factors affecting student performance in the introductory micro-economics course at UNISA found that language, amongst other factors, affects student success. They suggested that the institution should urgently address the language proficiency of students not studying in their home language (2006:155).

Other authors, however, have found a more tenuous link between home language and student performance/attrition, or even contradictory relationships. For example, Du Plessis, Müller and Prinsloo (2005:285) in their study of the factors influencing the success of first-year accounting students, also examined reading and comprehension skills as one of these factors. Their findings showed that although language was identified as a possible predictor of success, “... a clear-cut picture regarding language did not present itself." It seemed, from their research that although SLLs lagged behind, no significance could be attached to this fact. McMillan (2005) in a longitudinal survey of the Australian youth, found that English home-language learners rather than SLLs were more likely to drop out. Her research is supported by the research of Lamb, Robinson and Davies (2001), Martin, Maclachlan and Karmel (2001), Vickers, Lamb and Hinkley (2003), as well as Walstab, Golding, Teese, Charlton and Polesel (2001). Thus it seems that, while the LOTL may impact upon the performance and success of SLLs (Bohlmann \& Pretorius 2002), it may not necessarily impact directly upon SLL attrition rates per se.

Notwithstanding these apparent contradictions, which the paper reverts to in the discussion that follows, it is the concept of 'linguistic modification' as discussed by Abedi (2009) earlier in this section that sets the scene for the methodology underpinning this article which is discussed in the next section. The DMRM, faced with the challenge of improving student success and throughput rates amongst a student population for their capstone module where on average 43 percent of students are SLLs, decided to attempt to linguistically modify an assessment instrument that had been used before for the module's summative assessment. The objective of exercise was to attempt to 'linguistically simplify' the assessment instrument, while keeping the underlying questions about the theory the same. The simplified assessment instrument would then be used again for an upcoming summative assessment for the module in question (i.e. in 2009).

\section{METHODOLOGY}

The first step in this research was for the senior lecturers within the DMRM to revisit the 2007 year-end (October/November) examination paper for the DMRM's capstone module, namely Marketing Management (MNM202Y). Their objective was to attempt to simplify/modify the underlying linguistics of the essay questions as much as possible. Although the paper comprised both multiple-choice questions and essay questions, the study focused only on the essay questions. The 2007 examination paper comprised three essay questions worth 25 marks each, of which students have to answer any two.

The senior staff, comprising six staff members with more than 100 years of higher education experience between them, came together as a group during the course of a morning and took the questions, and debated how each question could be simplified in meaning (i.e. linguistically and semantically) without losing the theoretical essence of the questions concerned. One of the team members acted as facilitator and recorded the changes as the team worked through the questions. The 'before' and 'after' questions are attached as appendix A.

The revised questions were compiled into a new examination paper which became the official examination paper for the 2009 second semester examination period, with the examinations being written in October/November 2009. As the module in question is offered on a semester basis, the 2009 examination represented four examination periods since the 2007 examination, providing enough time for most supplementary students to complete the module This ensured that the two groups under investigation were unique (any remaining duplicate students were removed from the subsequent analysis). It is important to stress that the study material and prescribed book used by the two groups were identical, ensuring that the prescribed study material did not influence the results. In addition, the student support provided to the two groups was by the same individual and was similar over the two periods in question. 
The students' results in the two examinations were captured and analysed using an independent two-sample t-test. The two independent samples in question represented the 2007 and 2009 second semester students that wrote the final summative examination. In the 2007 examination, 1501 students wrote the examination, while in the 2009 examination, 1892 students wrote the examination. For the sake of comparison, the written mark (out of 50) was converted to a percentage and these percentages were used for the subsequent analysis. In both years, the students were divided into three groups; students with English as their home language, students with Afrikaans as their home language, and all other students with another language (other than English and Afrikaans) as their home language.

The main hypothesis underpinning this study is thus:

$\mathbf{H}_{\mathbf{0}}$ : $\quad$ The linguistic complexity of the essay questions used in the summative assessment for the Marketing Management module at UNISA, has no direct effect on student performance for students whose home language is not English or Afrikaans.

The formula used for the t-test is as follows:

$t=\frac{\bar{x}_{1}-\bar{x}_{2}-\Delta}{\sqrt{\frac{s_{1}^{2}}{n_{1}}+\frac{s_{2}^{2}}{n_{2}}}}$

where $x_{1}$, and $x_{2}$ are the means of the two samples, $\Delta$ is the hypothesized difference between the population means ( 0 if testing for equal means), $s_{1}$ and $s_{2}$ are the standard deviations of the two samples, and $n_{1}$ and $n_{2}$ are the sizes of the two samples. The number of degrees of freedom for the problem is the smaller of $n_{1}-1$ and $n_{2}-1$.

\section{FINDINGS}

Because of the large number of results obtained from SPSS given the various groupings used, the tables outlining the full set of results are only available from the authors. Only the key statistics have been summarized below:

Table 1: Summary of results: Group statistics -

Comparing how the students with different home languages faired against each in a particular year

\begin{tabular}{|c|c|c|c|c|}
\hline Year of comparison & $\begin{array}{c}\text { Home language } \\
\text { comparisons }\end{array}$ & $\mathbf{N}$ & Mean & Standard deviation \\
\hline \multicolumn{5}{|c|}{ English home language learners vs second language learners } \\
\hline \multirow[t]{2}{*}{2007} & English & 737 & 43.93 & 16.70 \\
\hline & SLLs & 592 & 40.33 & 16.24 \\
\hline \multirow[t]{2}{*}{2009} & English & 737 & 38.14 & 17.82 \\
\hline & SLLS & 838 & 35.54 & 15.92 \\
\hline \multicolumn{5}{|c|}{ Second language learners vs Afrikaans home language learners } \\
\hline \multirow[t]{2}{*}{2007} & SLLs & 592 & 40.33 & 16.24 \\
\hline & Afrikaans & 172 & 44.05 & 16.15 \\
\hline \multirow[t]{2}{*}{2009} & SLLs & 877 & 35.54 & 15.92 \\
\hline & Afrikaans & 177 & 37.25 & 18.17 \\
\hline \multicolumn{5}{|c|}{ English home language learners vs Afrikaans home language learners } \\
\hline \multirow[t]{2}{*}{2007} & English & 172 & 58.55 & 16.99 \\
\hline & Afrikaans & 177 & 56.78 & 17.88 \\
\hline \multirow[t]{2}{*}{2009} & English & 172 & 44.05 & 16.15 \\
\hline & Afrikaans & 177 & 37.25 & 18.17 \\
\hline
\end{tabular}


Table2: Summary of results: Comparison of independent samples (t-test) -

Comparing how the students with different home languages faired against each other in a particular year

\begin{tabular}{|c|c|c|c|c|c|}
\hline $\begin{array}{c}\text { Within year } \\
\text { comparisons }\end{array}$ & $\begin{array}{l}\text { EVA or } \\
\text { EVNA }\end{array}$ & t-value & $\begin{array}{c}\text { Sig. } \\
\text { (p-value) }\end{array}$ & $\begin{array}{c}\text { Which language did } \\
\text { better? }\end{array}$ & $\begin{array}{c}\text { Reject/Accept } \\
\mathbf{H}_{0} \\
\end{array}$ \\
\hline \multicolumn{6}{|c|}{ English home language learners vs second language learners } \\
\hline 2007 & EVNA & 3.965 & .000 & English & Reject $($ Sig<0.05) \\
\hline 2009 & EVA & 3.191 & .001 & English & Reject $($ Sig<0.05) \\
\hline \multicolumn{6}{|c|}{ Second language learners vs Afrikaans home language learners } \\
\hline 2007 & EVNA & -2.655 & .008 & Afrikaans & Reject $($ Sig<0.05) \\
\hline 2009 & EVA & -1.277 & .202 & Not significant & Accept (Sig >0.05) \\
\hline \multicolumn{6}{|c|}{ English home language learners vs Afrikaans home language learners } \\
\hline 2007 & EVNA & -0.087 & .931 & Not significant & Accept $($ Sig $<0.05)$ \\
\hline 2009 & EVNA & 0.590 & .555 & Not significant & Accept $($ Sig $<0.05)$ \\
\hline
\end{tabular}

$* \mathrm{EVA}=$ Equal variances assumed/EVNA = Equal variances not assumed

Table 3: Summary of results: Group statistics - Comparing how the learners

with different home languages faired with the MCQ and essay questions between the two examination periods

\begin{tabular}{|c|c|c|c|c|}
\hline $\begin{array}{c}\text { MCQ vs essay } \\
\text { questions }\end{array}$ & Year comparisons & $\mathbf{N}$ & Mean & Standard deviation \\
\hline \multicolumn{5}{|c|}{ English home language learners comparison 2007 vs 2009} \\
\hline \multirow[t]{2}{*}{ Essay } & 2007 & 737 & 43.93 & 16.70 \\
\hline & 2009 & 838 & 38.14 & 17.82 \\
\hline \multicolumn{5}{|c|}{ Second language learners comparison 2007 vs 2009} \\
\hline \multirow[t]{2}{*}{ Essay } & 2007 & 592 & 40.33 & 16.24 \\
\hline & 2009 & 877 & 35.54 & 15.92 \\
\hline \multicolumn{5}{|c|}{ Afrikaans home language learners comparison 2007 vs 2009} \\
\hline \multirow[t]{2}{*}{ MCQ } & 2007 & 172 & 58.55 & 16.99 \\
\hline & 2009 & 177 & 56.78 & 17.88 \\
\hline \multirow[t]{2}{*}{ Essay } & 2007 & 172 & 44.05 & 16.15 \\
\hline & 2009 & 177 & 37.25 & 18.17 \\
\hline
\end{tabular}

Table4: Summary of results: Comparison of independent samples (t-test) - Comparing how the learners with different home languages faired with the MCQ and essay questions between the two examination periods

\begin{tabular}{|c|c|c|c|c|c|}
\hline $\begin{array}{c}\text { MCQ vs } \\
\text { essay questions }\end{array}$ & $\begin{array}{c}\text { EVA or } \\
\text { EVNA }\end{array}$ & $\mathbf{t}$ & $\begin{array}{c}\text { Sig. } \\
\text { (p-value) }\end{array}$ & $\begin{array}{c}\text { Which year did } \\
\text { better? }\end{array}$ & $\begin{array}{c}\text { Reject/Accept } \\
\text { H}_{\mathbf{0}}\end{array}$ \\
\hline English home language students comparison 2007 vs 2009 & 2007 & Reject (Sig<0.05) \\
\hline MCQ & EVA & 3.424 & .001 & 2007 & Reject (Sig<0.05) \\
\hline Written & EVA & 6.622 & .000 & 2007 & Reject (Sig<0.05) \\
\hline Second language learners comparison 2007 vs 2009 \\
\hline MCQ
\end{tabular}

$* \mathrm{EVA}=$ Equal variances assumed/EVNA = Equal variances not assumed

From Tables 1 and 2 above, it can be seen that English home language learners outperformed SLLs in both years as their mean percentage scores were statistically significantly higher than those of the SLLs. Similarly, Afrikaans home language learners also outperformed SLLs in both years, as they also had higher mean percentage scores, but in 2009 the difference was not found to be statistically significant. Finally, English home language learners appeared to outperform Afrikaans home language learners in both years (with higher mean percentage scores), but in neither year was the difference statistically significant. 
It would seem that SLLs definitely perform less well with the essay (or written) component of the summative examination than their English counterparts. The SLLs also appeared to perform less well than the Afrikaans learners, but while in 2007 the difference was statistically significant, in 2009 it was not. Afrikaans home language learners also appear to struggle a bit more with the written examination than English home language learners, but the difference cannot be said to be significant.

The findings suggest that all three groups of students (English, Afrikaans and other home language learners) all did significantly worse in their 2009 examination compared with the 2007 examination. This suggests that the efforts of the team to simplify the linguistic complexity of the examination questions had a negative effect on student performance, not the positive effect that was hypothesised. Therefore the null hypothesis, as stated, that the linguistic complexity of the essay questions has no effect on the student performance, must be accepted.

\section{DISCUSSION}

The decline was somewhat unexpected, but, on reflection, there may be several reasons for this decline. These include:

- $\quad$ The efforts of the senior staff team were misguided and the questions were not actually linguistically simpler, but rather more complex.

- $\quad$ The class of 2009 comprised inherently less capable students than the class of 2007.

- $\quad$ One or more other factors as highlighted in the literature survey played a role in the results.

A post facto analysis of the efforts of the senior staff suggests that one serious drawback was that the team comprised only white males, four of whom were English speakers, one was an Afrikaans speaker, and the last member was bilingual (in English and Afrikaans). None of the team members were second-language lecturers and none had any linguistic training or experience. While this apparently is a shortcoming in approach to this research, it is indicative of many departments within the College.

When looking at the broader UNISA student population further trends become clear with regards to language preferences. For instance it is evident that the trend is towards more students (and specifically the younger generation) speaking primarily English and even preferring English as a language of choice (see the work of Setati (2008), who also holds this view). To a large extent this may be attributable to the greater use of social networks such as Twitter, Facebook, LinkedIn and MySpace. Students who are Afrikaans have shown a trend to adopting English as their preferred language of study. This is evidenced by the fact that only $17 \%$ of Afrikaans students who enrolled for MNM202Y chose to complete their examination in Afrikaans. The remaining 83\% (of Afrikaans speakers) chose to write their examination in English (UNISA 2010).

Many SLL students maybe feel that English is the language of the 'liberated' and a modern language (another view supported by Setati (2008)), even though they may not be as fluent in English as is required for tertiary studies.

The fact that the 'other' students performed less well than English language students can possibly also be related to their standard and level of pre-university education. Many of these students may have been tutored in English but the standard may not have been adequate, as it is generally known that rural and 'township' schools do not attract the best teachers and this impacts on the learners' formative development which will eventually impact on his or her performance in later years, especially at university.

The fact that all three groups of students did significantly worse in 2009 compared to 2007 could be accredited to the severe economic hardship they have incurred due to the prolonged worldwide economic recession which started late in 2007 by was really felt in 2008. During 2007 the economic conditions were very favourable and it can be assumed that students found it easier to cope. Money was more freely available through own funds or family/support structures. This, however, changed dramatically during 2008 and worsened in 2009 when economic hardship was the order of the day. It can be assumed many students experienced more pressure in their work or were even retrenched. This, arguably, puts further strain on students to focus on survival and not on their studies. These 
assumptions are supported by a analysis of the profile of students, where $57 \%$ were employed in 2007, compared to $53 \%$ who indicated they were employed in 2009 (UNISA 2010).

A final inference that can be drawn from these findings is that students who have a better grasp of the English language will always do better than those who do not - even where the language has been simplified to a level that is uncomplicated, clear and easy to understand

\section{CONCLUSIONS}

With the findings in mind, there are essentially two conclusions that can be drawn from this study. The first is that SLLs do indeed perform less well than learners with English or Afrikaans as their home language. The difference is statistically significant, although not very large and is in line with the findings of most other researchers in this field.

This suggests that as proposed by Abedi (2009) linguistic accommodations could have a positive impact on the performance of SLLs. The linguistic accommodations proposed by $\mathrm{xxx}$ include multilingual dictionaries, multilingual definitions of key terms, linguistic modification of assessments, etc.

The second conclusion that can be drawn from this study is that the efforts of the DMRM senior staff to improve student performance (particularly, but not only, of SLLs) by linguistically simplifying the essay question component of the summative assessment instrument, were unsuccessful. The conclusion raises a number of questions such as: 'Were the modified questions actually simpler?' and 'Might the drop in student performance be attributable to other factors?' Further research is clearly warranted.

The issue of linguistic complexity applied to assessment in higher education remains an issue without a comfortable conclusion. Rather than bringing clarity to this topic, this study has identified further research opportunities in the ongoing quest to improve student performance.

\section{AUTHOR INFORMATION}

Cornelius Bothma is a senior lecturer in the Department of Marketing and Retail Management at UNISA. Cornelius is currently working on his doctorate - he holds an M Bus Sc degree from the University of Cape Town. He has authored and co-authored more than ten books on e-commerce, international business and marketing, and has contributed to a further 15 books on related topics. His research interests include international marketing and education within an ODL context. It is from within this interest in ODL research that the article on linguistics was born. E-mail: bothmch@UNISA.ac.za

Prof Michael Cant is CoD Marketing and Retail management at the University of South Africa. He has published over 15 accredited articles in refereed journals and is the editor and author of more than 20 books in marketing. These books are widely prescribed at universities in South Africa. He has presented papers at more than 45 international conferences all over the world and is a well respected marketing and retail scholar. He holds a $\mathrm{PhD}$ in Marketing from the University of South Africa. E-mail: cantmc@UNISA.ac.za. Corresponding author.

Mr Michael du Toit is a marketing lecturer in the Department of Marketing and Retail Management at UNISA. He is co-author of a number of marketing books specializing in sales, customer service and consumer loyalty. Mr du Toit's study interests are in web usability and online marketing in which areas he is currently pursuing a Doctorate degree. E-mail: Dtoitm3@UNISA.ac.za

\section{REFERENCES}

1. Abedi, J. 2004. The No Child Left Behind Act and English Language Learners: Assessment and accountability issues. Educational Researcher, Vol. 33, No.1, p 4.

2. Abedi, J. 2009. Validity of assessments for English language learning students in a national/international context. Estudios sobre Educación, 2009, 16, 167-183. 
3. Abedi, J., and Gándara, P. (2006). Performance of English language learners as a subgroup in large-scale assessment: Interaction of research and policy. Educational Measurement: Issues and Practice, 25(40), 3646.

4. Abedi, J., Leon, S., and Mirocha, J. 2003. Impact of students' language background on content-based assessment: Analyses of extant data. CSE Technical Report No. 603. University of California, National Center for Research on Evaluation, Standards, and Student Testing, LA.

5. Adegbile, J.A. and Oyekanmi, J.O. 2009. Assessment of support facilities available to degree programme distance learning students in the Southwestern Nigerian universities. Educational Research and Review Vol. 4 (2), pp. 042-047, February 2009.

6. Al-Qarni, I.R. 2008. Intensive productive vocabulary language: A single subject case of Arabic as a foreign language. Language and Translation, Vol. 20, pp. 51-59.

7. Anon 2006. Barriers to Teaching \& Learning adapted from www.open.ac.uk/inclusiveteaching/pages/inclusiveteaching/recognising-bariers-mental-healthdifficulties.php, The Open University.

8. Astin, A. W. 1998. The changing American college student: Thirty-year trends, 1966- 1996. The Review of Higher Education, 21(2), 115- 135.

9. August, D., and Shanahan, T. 2006. (Ed.). Developing literacy in second-language learners. Mahwah, NJ: Lawrence Erlbaum Associates. p.5.

10. Bane, M. 2008. Quantifying and measuring morphological complexity. Paper presented at the 26th West Coast Conference on Formal Linguistics and published in the conference proceedings (ed. Charles B. Chang and Hannah J. Haynie), pp. 69-76. Somerville, MA.

11. Bean, J. P. 1980. Dropouts and turnover: The synthesis and test of a causal model of student attrition. Research in Higher Education, 12, 155-187.

12. Bean, J. P., and Eaton, S. 2000. A Psychological Model of College Student Retention, edited by J. M. Braxton, 73-89. Nashville, TN: University of Vanderbilt Press.

13. Bean, J. P. and Metzner, B. 1985. A conceptual model of non-traditional undergraduate student attrition. Review of Educational Research 55 (4), 485-540.

14. Bharuthram, S. 2006. Developing reading strategies in higher education through the use of integrated reading/writing activities: a study at a university of technology in South Africa. Doctoral thesis submitted at University of KwaZulu-Natal, December 2006. p. 14.

15. Bohlmann, C.A. and E.J. Pretorius. 2002. Reading skills and mathematics. The South African Journal of Higher Education, 16(3):196-206.

16. Boles, W. 2008. Overcoming barriers to student learning: A guide for academics. A report prepared on behalf of the ALTC Fellowship Program, a joint venture between the Queensland University of Technology and the Australian Learning and Teaching Council.

17. Browning, G., Brinton, D., Ching, R., Dees, R. Dunlap, S., Erickson, M. Garlow, K., Manson, M. and Sasser, L. 2000. The second language student in public high schools, colleges, and universities. California Pathways, Community Colleges Chancellor's Office, Sacramento. p. 6.

18. Cabrera, A.F., Nora, A. and Castańeda, M.B. 1992. The role of finances in the persistence process: A structural model. Research in Higher Education, Vo. 33, No. 5, 1992.

19. Cao, Z. And Gabb, R. 2006. Student attrition at a new generation university. Report published by the Postcompulsory Education Centre, Victoria University, Melbourne.

20. DeRemer, M. A. The adult attrition process (ASADP) model. Doctoral thesis submitted to the University of Texas, Austin, December 2002.

21. DesJardins, S. L., Ahlburg, D. A., and McCall, B. P. (1999). An event history model of student departure. Economics of Education Review 18: 375-390.

22. Du Plessis, A., P. Prinsloo and H. Müller. 2005. Determining the profile of the successful first-year Accounting student. The South African Journal of Higher Education, 19(4):684-698.

23. Gándara, P., Rumberger, R., Maxwell-Jolly, J and Callahan, R. 2003. English learners in California schools: Unequal resources, unequal outcomes. EPAA, Vol. 11, No. 36, October 2003.

24. Gqola, P. 2001. Defining people: Analysing power, language and representation in metaphors of the New South Africa. Transformation No. 47, 2001. pp. 94-106.

25. Grimes, P.W. 2002. The overconfident principles of economics student: An examination of a metacognitive skill. Journal of Economic Education, Winter: 15-30. 
26. Hawkins, J. A. (Apr 2007). 'An efficiency theory of complexity and related phenomena'. Conference on Complexity as an Evolving Variable, Max Planck Institute for Evolutionary Anthropology, Leipzig, Germany.

27. Horn, C.A. English second language learners: using music to enhance listening capabilities of grade ones. Master's thesis submitted to the University of South Africa, February 2007. p. 2.

28. Howie, S. 2004. A national assessment in mathematics within an international comparative assessment. Perspective in Education, Vol. 22 (2), June 2004.

29. Hummel, U.I. 2010. Barriers to Learning: The difference distance learning can make in Namibia. Centre for Open and Lifelong Learning, Polytechnic of Namibia. http://wikieducator.org/images/a/a8/Ulrich_Innozenz_Hummel.pdf

30. Irani, T., Scherler, C., Harrington, M., and Telg, R. 2000. Overcoming barriers to learning in distance education: The effects of personality type and course perceptions on student performance. Paper published in the proceedings of the $27^{\text {th }}$ Annual National Agricultural Education Research Conference. pp. 434-447.

31. Kanjira, T. J. Motivation and attitudes towards English as a second language (ESL) among learners in rural Kwazulu-Natal high schools. Master's dissertation submitted to University of Kwazulu-Natal, March 2008. p. 37.

32. Kember. D. 1989. A longitudinal-process model of dropout from distance education. Journal of Higher Education, 60(3): 278-301.

33. Kusters, W. 2003. Lingusitic complexity: The influence of social change on verbal inflection. Doctoral thesis submitted to the University of Leiden, Centre of Linguistics, The Netherlands.

34. Lamb, S., Robinson, L. \& Davies, M. 2001. Youth Allowance and participation in education, training and work: Results from the third wave of the Youth Allowance Longitudinal Survey. Report prepared for the Youth and Students Branch, Department of Family and Community Services. Melbourne: Australian Council for Education Research.

35. Lee, P. 1997. Cognitive development in bilingual children. A case for bilingual instruction in early childhood instruction. Bilingual Research Journal, 20, 99-522.

36. Mahabeer, S.D. 2003. Barriers in acquiring basic English reading and spelling skills by Zulu-speaking foundation phase learners Master's dissertation submitted to the University of South Africa, November 2003.

37. Maitland, I.D.M. (2010). Tutor mentoring of foundation mathematics at Monash South Africa. Doctoral thesis submitted at UNISA, February 2010. p. 63.

38. MacKinnon-Slaney, F. 1994. The adult persistence in learning model. Journal of Counseling \& Development. 72 (3), 268-275.

39. Martin, F. M.D.P. 2010. The effective complexity of language: English requires at least an infinite grammar. Paper submitted for publishing in Cognition, October 2010.

40. Martin, Y.M., Maclachlan, M. and Karmel, T. 2001. Undergraduate completion rates: An update. Occasional paper 01/F. Canberra: DEST. Retrieved 27 March2011 from

41. McMillan, J. 2005. Course change and attrition from higher education. Research Report 39, Australian Council for Educational Research.

42. McMillan, J. 2005. Course change and attrition from higher education. Report published by the Australian Council for Educational Research, June 2005.

43. Mhehe, E. 2002. Women overcoming barriers to learning by distance at the Open University of Tanzania. Online resource

44. Miestamo, M. 2004. On the feasibility f complexity metrics. Paper presented to the Complexity workshop at the FinEst Conference of Linguistics, Tallinn Pedagogical University, May 7, 2004

45. Ngwenya, M. D. 2004. The imaging technique as learning support for educationally disadvantaged learners in the secondary school, to improve reading comprehension. Master's dissertation submitted at the University of Pretoria, August, 2004.

46. Omidire, M.F. 2009. Investigating dynamic assessment as a means of addressing the assessment dilemma of additional language learners. Doctoral thesis submitted to the University of Pretoria in 2009.

47. Ozga, J. and Sukhnandan, L. 1998. Undergraduate Non-Completion: Developing an Explanatory Model. Higher Education Quarterly 5 Vol 2 pp. 316-333.

48. Pascarella, E. 1980. Student-faculty informal contact and college outcomes. Review of Educational Research 50, 545-95. 
49. Pityana, N.B. 2009. Flexible Education for All: Open -Global - Innovative. Keynote speech delivered on the occasion of the M - 2009 23rd ICDE World Conference on Open Learning and Distance Education, 7 10 June 2009, Maastricht, the Netherlands.

50. Posel, D. and Casale, D. 2010. English language proficiency and earnings in a developing country: The case of South Africa. A paper presented at the DPRU/TIPS conference held in Johannesburg from 27-29 October 2010.

51. Pretorius, A. M., Prinsloo, P. and Uys, M. D. 2009. Student performance in Introductory Microeconomics at an African open and distance learning institution', Africa Education Review, 6: 1, 140-158

52. Prinsloo, P. and Subotzky, G. 2010. Towards a framework and strategy for enhancing student success, retention, graduation and satisfaction at UNISA. Draft proposals prepared by Task Team 6 for the Senate Tuition and Student Support Committee. Pretoria: UNISA.

53. Reviere, R. 2001. Rethinking open and distance education practices: Unearthing subjectivities and barriers to learning

54. Seeff-Gabriel, B. 2003. Phonological processing: a platform for assisting second-language learners with English spelling. Child Language Teaching and Therapy 2003 19: 292

55. Setati, M. 2008. Access to mathematics versus access to the language of power: the struggle in multilingual mathematics classrooms. South African Journal of Education. 28(1):103-116.

56. Setati, M. Chitera, N. and Essien, A. 2009. Research on multilingualism in mathematics education in South Africa: 2000-2007. African Journal of Research in MST Education, Special Issue 2009, pp. 65-80.

57. Spady, W.G. 1970. Dropouts from higher education: An interdisciplinary review and synthesis. Interchange, 1:64-85.

58. Straker, S. 2008. Investigation into the differences and similarities between English first language and English foreign language teachers' attitudes towards the explicit teaching of grammar in their classrooms. Master's dissertation submitted to the University of the Witwatersrand. p.10.

59. Stratton, L. S., O’Toole, D.M. and Wetzel, J.N. 2006. Are the factors affecting dropout behaviour related to initial enrolment intensity for college undergraduates? Discussion paper No. 1951 prepared for the Institute for the Study of Labor (IZA), Germany.

60. Tangen, D. 2007. A contextual measure of teacher efficacy for teaching primary school students who have ESL. Doctoral thesis submitted to the Queensland University of Technology in September 2007. p.1.

61. Thurlow, L.D. 2004. Distance education and second language instruction: An analysis and recommendations for integration. Masters dissertation submitted to Athabasca University, January 2004.

62. Tinto, V. 1975. Dropout from higher education: A theoretical synthesis of recent research. Review of Educational Research, 45:89-125.

63. Tinto, V. 1993. Leaving college: rethinking the causes and cures of student attrition. Chicago: University of Chicago Press.

64. Unesco, 2002. Open and distance learning: Trends, policy and strategy considerations. United Nations Educational, Scientific and Cultural Organization, Paris.

65. Unesco. 2005. Mega universities. United Nations Educational, Scientific and Cultural Organization, Paris.

66. UNISA. 2010. Student language and examination statistics, sourced from internal documents and data.

67. Van Schoor, W. 2011. You can lead a horse to water but you can't make it drink: The development of transformed situated agency to facilitate the integration of students into institutions. Paper presented at the First Year in Higher Education conference held in Freemantle from 28 June to 1 July 2011.

68. Van Zyl, D., Subotzky, G. and Liebenberg, H. 2011. Student success: Challenges of meaningfully profiling a highly heterogeneous student body to inform effective interventions - the case of the University of South Africa. Paper presented at the HEIR Conference 2011 in London from 16 to 17 June 2011.

69. Vickers, M., Lamb, S. \& Hinkley, J. 2003. Student workers in high school and beyond: The effects of parttime employment on participation in education, training and work. LSAY Research Report No. 30.

Melbourne: ACER. P. 26

70. Vidanapathirana, U. and Gamini, L.P.S., 2009. Medium of instruction, language proficiency and learner profiles: Impacty of English proficiency on the performance of learners following the BA degree in Social Sciences. OUSL Journal, Vol. 5, pp. 41-59.

71. Walstab, A., Golding, B., Teese, R., Charlton, M. \& Polesel, J. (2001). Attrition and wastage in tertiary education: Report. Canberra: Lifelong Learning Network, University of Canberra. 
72. Wang, S. C. and sGarcœa, 2002. M.I. Heritage language learners. Position paper prepared on behalf of the National Council of State Supervisors of Foreign Languages.

73. Wu, M-P., and Hsieh, S-W. 2008. The comparison of oral language acquisition for grade 1-3 in Taiwan and America. International Journal of Instruction, July 2008, Vol. 1, No. 2. 


\section{APPENDIX A}

\section{THE QUESTIONS}

The two sets of questions used for the October 2007 and 2009 summative examinations respectively. These sets of questions were based on a mini-case study which is provided below the table.

\begin{tabular}{|c|c|}
\hline 2007 (October) & 2009 (October) \\
\hline \multicolumn{2}{|l|}{ QUESTION 1 [25 marks] } \\
\hline \multicolumn{2}{|l|}{ a) (15 marks) } \\
\hline $\begin{array}{l}\text { Lurpak have selected health conscious customers as their target } \\
\text { segment for the new product. Discuss the benefits and } \\
\text { drawbacks of market segmentation and provide practical } \\
\text { examples for Lurpak that demonstrate each of the benefits and } \\
\text { drawbacks. } \\
\text { The marks for this question will be awarded as follows: } \\
\text { Theoretical discussion of the benefits and drawbacks of market } \\
\text { segmentation - } 10 \text { marks } \\
\text { Practical examples - } 5 \text { marks }\end{array}$ & $\begin{array}{l}\text { Lurpak have selected health conscious customers as their target } \\
\text { segment for the new product. } \\
\text { (i) Discuss four (4) benefits (advantages) for Lurpak of } \\
\text { market segmentation. ( } 9 \text { marks) } \\
\text { (ii) Discuss three (3) drawbacks (disadvantages) for Lurpak } \\
\text { of market segmentation (6 marks) }\end{array}$ \\
\hline \multicolumn{2}{|l|}{ b) $(10$ marks $)$} \\
\hline $\begin{array}{l}\text { The 'marketing mix' consists of four elements. Briefly discuss } \\
\text { these four elements and provide examples that apply to Lurpak } \\
\text { to demonstrate each one of the elements. } \\
\text { The marks for this question will be awarded as follows: } \\
\text { Theoretical discussion of the marketing mix - } 6 \text { marks } \\
\text { Practical examples - } 4 \text { marks }\end{array}$ & $\begin{array}{l}\text { The case study does not provide adequate information of } \\
\text { Lurpak's use of the marketing mix (the four p's). Give a short } \\
\text { description of the marketing mix and suggest how Lurpak } \\
\text { could apply the four p's in the marketing of their butter. (10 } \\
\text { marks) }\end{array}$ \\
\hline \multicolumn{2}{|l|}{ QUESTION 2 [25 marks] } \\
\hline $\begin{array}{l}\text { When consumers decide about which product or service to } \\
\text { purchase they are influenced by both individual and group } \\
\text { factors. Imagine a consumer is standing in a retail shop about } \\
\text { to purchase a Lurpak Lighter Spreadable butter. Discuss the } \\
\text { group factors that would influence their purchase decision and } \\
\text { demonstrate your understanding of the theory by using } \\
\text { practical examples of each group factor that applies to the } \\
\text { purchasing of Lurpak butter. } \\
\text { The marks for this question will be awarded as follows: } \\
\text { Theoretical discussion of the group factors - } 21 \text { marks } \\
\text { Practical examples - } 4 \text { marks }\end{array}$ & $\begin{array}{l}\text { Discuss the five (5) group factors that influence consumers' } \\
\text { buying decisions and explain how each of these group factors } \\
\text { could influence the decision to purchase Lurpak butter. }\end{array}$ \\
\hline \multicolumn{2}{|l|}{ QUESTION 3 [25 marks] } \\
\hline \multicolumn{2}{|l|}{ a) (20marks) } \\
\hline \multicolumn{2}{|l|}{$\begin{array}{l}\text { The marks for this question will be awarded as follows: } \\
\text { Theoretical discussion of the macro-environment- } 14 \text { marks } \\
\text { Practical examples of the Lurpak macro- environment - } 6 \\
\text { marks }\end{array}$} \\
\hline \multicolumn{2}{|l|}{ b) (5 marks) } \\
\hline $\begin{array}{l}\text { Briefly discuss the marketing information system. } \\
\text { The marks for this question will be awarded as follows: } \\
\text { Theoretical discussion of the marketing information system - } 5 \\
\text { marks }\end{array}$ & $\begin{array}{l}\text { The marketing information system (MIS) has four components. } \\
\text { Briefly explain these four components. }\end{array}$ \\
\hline
\end{tabular}


The mini case study

\section{LURPAK BUTTER}

Patleys have expanded their range of Danish Lurpak butter with the launch of new Lurpak Lighter Spreadable, a blend of butter and vegetable oil with $25 \%$ less fat than regular butter. This new Lighter Spreadable variant will not only make life easier for existing Lurpak consumers who will love its authentic rich and creamy taste, but also offers health conscious consumers a lower fat alternative. Lurpak have identified "FatGo" as the suppliers of the new vegetable oil. They are hoping to compete more directly with Flora Light by making Lurpak available in Spar and Woolworths stores. 